\title{
PENGARUH EFIKASI DIRI DAN KEPERCAYAAN TERHADAP KOMITMEN ORGANISASI PEGAWAI DINAS PENDIDIKAN PROVINSI PAPUA BARAT
}

\author{
Jamiah Qomariah* $^{*}$
}

\begin{abstract}
The objective of this research is to know the effect of self efficacy and trust toward organizational commitment of employee of the education department at the Province of West Papua.The research was conducted using survey method with quantitative approach and path analysis technique. The population of this research is 80 employees. Research samples selected as much as 67 employees using simple random sampling technique. The data obtained through questionnaires and analyzed using path analysis techniques. Based on the results of data analysis in this research it is concluded: (1) self efficacy have positive direct effect to organizational commitment; (2) trust have positive direct effect to organizational commitment; (3) self efficacy have positive direct effect to trust. The organizational commitment can be improved through improvement of self efficacy and trust.
\end{abstract}

Key Words: Organizational Commitment, Self Efficacy, and Trust

\section{PENDAHULUAN}

Masih banyak pegawai yang memiliki komitmen organisasi yang rendah. Indikasinya antara lain tampak dari adanya perilaku pegawai yang tidak sesuai dengan nilai-nilai organisasi seperti menggunakan fasilitas kantor untuk kepentingan pribadi, menggunakan jam kerja untuk keperluan pribadi, mengambil waktu istirahat melebihi ketentuan jam istirahat, tidak mengindahkan atau kurang loyal terhadap perintah atau supervisi atasan, serta kurang serius dan intens dalam melaksanakan tugas atau pekerjaan. Selain itu, data kepegawaian pada Dinas Pendidikan Provinsi Papua Barat (periode Janurai-Juni 2013) menunjukkan bahwa pegawai yang terlambat masuk kantor mencapai 8\%. Gillham, Reivich dan Shatté (2002:121), "individuals with high self-efficacy is committed to solving the problem and will not give up when it finds that the strategies that are being used that did not work. Pengertian ini dimaksudkan bahwa individu dengan efikasi diri tinggi memiliki komitmen dalam memecahkan masalahnya dan tidak akan menyerah ketika menemukan bahwa strategi yang sedang digunakan itu tidak berhasil. Robbins dan Judge (2009:392) menyebutkan lima dimensi kunci dalam konsep kepercayaan yang dapat dijadikan indikator pengukuran kepercayaan, yaitu: integritas (integrity), kompetensi (competence), konsistensi (consistency), loyalitas (loyalty) dan keterbukaan (openness). Lussier (1996:81) menyatakan bahwa "self-efficacy is capability owned to do something in special situation. Self-efficacy influences effort of a person, his or her persistence and interest in solvableness of difficulty from target that he or she selects." Efikasi diri merupakan kemampuan yang dimiliki untuk melakukan sesuatu dalam situasi yang khusus. Efikasi diri mempengaruhi upaya seseorang, kegigihannya dan minatnya dalam mengatasi kesulitan dari sasaran yang dipilihnya Hal ini mengisyaratkan bahwa komitmen pegawai masih kurang memadai. Maka dari itu peneliti ingin mengkaji secara ilmiah apakah efikasi diri dan kepercayaan berpengaruh terhadap komitmen organisasi pegawai pada Dinas Pendidikan Papua Barat.

\footnotetext{
* Guru pada SMA Negeri 1 Kaimana Papua Barat
} 


\section{Komitmen}

Mowdey, Porter dan Steers sebagaimana dikutip Slocum dan Hellriegel (2007:328) memberikan definisi komitmen organisasi sebagai berikut, "organizational commitment refers to the strength of an employee's involvement in the organizational and indentification with it, a support of and acceptance of the organization's goals and values, a willingness to exert considerable effort on behalf of the organization, and, a desire to remain with the organization".Komitmen organisasi merujuk pada kekuatan pegawai dalam mengidentifikasikan keterlibatan dirinya ke dalam bagian organisasi yang ditandai: penerimaan terhadap nilai-nilai dan tujuan organisasi, kesiapan dan kesediaan untuk berusaha dengan sungguh-sungguh atas nama organisasi, dan keinginan untuk mempertahankan keanggotaan di dalam organisasi.

Robbins dan Judge (2007:74), "organizational commitment is defined as a state in which an employee identifies with a particular organization and its goals and wishes to maintain membership in the organization". Komitmen organisasi didefinisikan sebagai keadaan di mana pegawai berpihak pada organisasi tertentu dan tujuannya, serta keinginannya untuk mempertahankan keanggotaannya dalam organisasi.

Definisi yang lain dikemukakan oleh Luthans (2008:147) dengan mengatakan, "organizational commitment is a strong desire to remain a member of a particular organization; a willingness to exert high levels of effort on behalf of the organization, and a definite belief in, and acceptance of, the values and goals of the organization". Komitmen organisasi merupakan suatu hasrat yang kuat untuk tetap menjadi anggota organisasi; suatu keinginan untuk menunjukkan usaha tingkat tinggi atas nama organisasi; dan keyakinan yang kuat dalam menerima nilai-nilai dan tujuan-tujuan organisasi

Definisi yang relatif berbeda dikemukakan oleh Newstrom dan Davis (2007:259) sebagai berikut; "organizational commitment is the degree to which an employee identifies with the organization and wants to continue actively participating in it. "Definisi ini merefleksikan bahwa komitmen organisasi merupakan derajat identifikasi diri pegawai dengan organisasi dan keinginan-keinginannya untuk meneruskan partisipasi aktifnya dalam organisasi.

Sedangkan menurut Ivancevich, Konopaske dan Matteson (2008:184), "organizational commitment is a sense of identification, involvement, and loyalty expressed by an employee toward the company." Komitmen organisasi adalah rasa kesediaan, keterlibatan, dan loyalitas yang diungkapkan oleh pegawai terhadap perusahaannya.

Dari uraian di atas dapat disintesiskan bahwa komitmen organisasi adalah keinginan seseorang untuk tetap bertahan dan meneruskan partisipasi aktifnya dalam organisasi, dengan indikator: kesesuaian diri dengan tujuan organisasi, keterlibatan dalam kewajiban-kewajiban organisasi, dan kesetiaan terhadap organisasi.. 


\section{Efikasi diri}

Menurut Redman dan Wilkinson (1999:43), "self efficacy is potential totality possessed by a person to implement assignment given to him or her. This proves to be important since it affects persistence and effort of a person in gain of success in his or her life." Efikasi diri merupakan totalitas potensi yang dimiliki seseorang untuk melaksanakan tugas yang diberikan kepadanya. Hal ini terbukti penting karena mempengaruhi ketekunan dan upaya seorang dalam mencapai kesuksesan dalam hidupnya.

Bagi Wright dan Noe (1996:353), "self-efficacy is also an assessment of a person on himself or herself, whether he is successful to implement an activity. A person who has a high self-efficacy will more attempt to setttle-out impediment or obstacle". Efikasi diri juga merupakan penilaian seseorang atas dirinya, apakah ia dapat sukses melaksanakan suatu kegiatan. Seseorang yang memiliki efikasi diri tinggi akan lebih berupaya dalam mengatasi hambatan atau rintangan yang dihadapinya.

Sedangkan Lussier (1996:81) berpendapat bahwa; "self-efficacy is capability owned to do something in special situation. Self-efficacy influences effort of a person, his or her persistence and interest in solvableness of difficulty from target that he or she selects." Efikasi diri merupakan kemampuan yang dimiliki untuk melakukan sesuatu dalam situasi yang khusus. Efikasi diri mempengaruhi upaya seseorang, kegigihannya dan minatnya dalam mengatasi kesulitan dari sasaran yang dipilihnya.

Baron dan Greenberg (2003:205) berpendapat bahwa "self efficacy is a relatively new topic in the study of organizational behavior, but have been identified have important implications that could affect performance on many different tasks". Efikasi diri merupakan topik yang relatif baru dalam studi perilaku organisasi, tetapi telah diindentifikasi memiliki implikasi penting yang dapat mempengaruhi kinerja pada banyak tugas yang berbeda.

Sedangkan Baron (1996:392) berpandangan bahwa, "self-efficacy is capability owned by a person in order to carry out action he wants. The higher the feeling of person about selfefficacy that he has, the better the tendency to do various duty. The success like that in the end has finnaly directed a person of positive feeling about himself or herself more comprehensively". Efikasi diri merupakan kemampuan yang dimiliki seseorang untuk dapat melaksanakan tindakan yang diinginkan. Semakin tinggi perasaan seseorang tentang efikasi diri yang dimilikinya maka semakin baik kecenderungannya untuk melakukan tugas yang lebih beragam. Keberhasilan seperti itu sudah tentu pada akhirnya dapat mengarahkan seseorang pada perasaan positif tentang dirinya secara lebih menyeluruh.

Selain itu, menurut Robbins (2009:180), "self-efficacy is also an individual's belief that he is able to carry out a task". Pengertian ini dimaksudkan bahwa efikasi diri juga merupakan keyakinan individu bahwa dirinya mampu menjalankan suatu tugas. Sedangkan Schultz dan Schultz (2006:360) mendefinisikan, "self-efficacy refers to the belief in one's ability to accomplish a task". Maksud pengertian ini adalah bahwa efikasi diri sebagai kepercayaan terhadap kemampuan seseorang untuk menyelesaikan suatu tugas. Carlson dan Buskist (1999:459) juga mengatakan, "self-efficacy is a form of competence owned by a person". Efikasi diri merupakan suatu bentuk kompetensi yang dimiliki seseorang.

Berdasarkan uraian di atas dapat disintesiskan bahwa efikasi diri adalah keyakinan seseorang atas kemampuannya melaksanakan tugas tertentu, dengan indikator: penguasaan pengalaman atau prestasi kerja, pengalaman sendiri atau peniruan, bujukan sosial, serta kebangkitan fisiologi dan psikologi. 


\section{Kepercayaan}

Colquitt, LePine dan Wesson (2009:219) mendefinisikan "trust is as the willingness to be vulnerable to a trustee based on positive expectations about the trustee's actions and intentions." Definisi ini pada intinya menekankan bahwa kepercayaan merupakan suatu keinginan untuk menggantungkan diri pada suatu otoritas yang didasarkan pada pengharapan positif akan tindakan dan perhatian otoritas. Bagi McShane dan Von Glinow (2008:120), "trust refers to positive expectations one person has toward another person in situations involving risk. Trust means putting faith in the other person or group"." Dalam hal ini, kepercayaan merujuk pada suatu pengharapan positif seseorang terhadap orang lain pada suatu situasi yang melibatkan risiko. Kepercayaan juga berarti menyerahkan nasib pada seseorang atau kelompok lain. Sedangkan Robbins dan Judge (2007:392) berpandangan bahwa "trust is a positive expectation that another will not-through words, actions, or decisions-act opportunistically." Artinya, kepercayaan adalah suatu pengharapan positif bahwa pihak lain tidak akan - lewat perkataan, tindakan atau keputusan - mengambil kesempatan melukai pihak lain..

Di pihak lain George dan Jones (2005:80) menyatakan bahwa, "trust is an expression of confidence in another person or group of people that you will not be put at risk, harmed, or injured by their actions". Kepercayaan adalah ungkapan keyakinan terhadap orang lain atau kelompok orang di mana Anda tidak akan berisiko, dihancurkan, atau dilukai oleh tindakan mereka. Sedangkan Rousseau et. al. sebagaimana dikutip Mollering (2006:7) memberikan definisi "trust as a psychological state that consists of a willingness to accept an unpleasant situation that is based on positive expectations of a desire or behavior of another party". Definisi tersebut menekankan makna bahwa kepercayaan merupakan suatu keadaan psikologis yang terdiri dari keinginan untuk menerima suatu keadaan yang tidak menyenangkan yang didasarkan pada pengharapan positif akan keinginan atau perilaku pihak lain.

Pandangan serupa dikemukakan oleh Mayer et al sebagaimana dikutip Mollering (2006:7) bahwa, "trust is a willingness of a party to accept the unpleasant actions of another party based on an expectation that the other party will perform a particular action is very important for the giver of trust, regardless of ability to supervise or control the other party". Definisi tersebut menjelaskan bahwa kepercayaan adalah suatu keinginan dari suatu pihak untuk menerima tindakan yang tidak menyenangkan dari pihak lain berdasar pada suatu pengharapan bahwa pihak lain akan melakukan tindakan tertentu yang sangat penting bagi si pemberi kepercayaan, terlepas dari kemampuan untuk mengawasi atau mengontrol pihak lain tersebut.

Robbins dan Judge (2007:392) menyebutkan lima dimensi kunci dalam konsep kepercayaan yang dapat dijadikan parameter pengukuran kepercayaan. Kelima dimensi tersebut meliputi: "(1) integrity, refers to honesty and truthfulness; (2) Competence, encompasses an individual's technical and interpersonal knowledge and skills; (3) Consistency, relates to an individual's reliability, predictability, and good judgment in handling situations; (4) Loyalty, is the willingness to protect and save face for another person; and (5) Openness". Kelima dimensi tersebut mengandung makna: (1) integritas (integrity), merujuk pada kejujuran dan kebenaran; (2) kompetensi (competence), terkait dengan pengetahuan dan keterampilan teknikal dan interpersonal yang dimiliki individu; (3) konsistensi (consistency), berhubungan dengan keandalan, kemampuan memprediksi dan penilaian individu jitu dalam menangani situasi; (4) loyalitas (loyality), keinginan untuk melindungi dan menyelamatkan orang lain; dan (5) Keterbukaan (openness).

Dari uraian di atas dapat disintesiskan bahwa kepercayaan adalah keinginan seseorang menggantungkan diri pada orang lain yang didasari harapan positif atas 
tindakan dan perhatian orang lain, dengan indikator: integritas, konsistensi, loyalitas, dan keterbukaan.

\section{METODE PENELITIAN}

Penelitian ini dilaksanakan di Dinas Pendidikan Provinsi Papua Barat. Penelitian ini dilaksanakan dari bulan Mei sampai Nopember 2013. Metode yang digunakan dalam penelitian ini adalah survey dengan menggunakan teknik kausal. Populasi adalah pegawai yang berstatus pegawai negeri sipil dan pegawai honorer pada Dinas Pendidikan Provinsi Papua Barat, dengan jumlah 80 orang yang berjumlah 80 orang dengan jumlah sampel sebanyak 67 orang. Data yang dikumpulkan dalam penelitian dijaring melalui kuesioner yang berupa skala penilaian (rating scale) dengan sebaran skor antara 1 sampai dengan 5. Sebelum kuesioner digunakan dalam penelitian ini, terlebih dahulu dilakukan ujicoba untuk menentukan validitas dan reabilitas instrumen. Hasil tersebut digunakan sebagai instrumen untuk mengambil data dalam penelitian di lapangan. Analisis data meliputi: 1) deskripsi data; 2) uji prasyarat analisis normalitas; 3) analisis jalur yang meliputi: analisis model regresi, pengujian hipotesis dan penentuan tingkat pengaruh dengan menggunakan teknik analisis jalur (path analysis).

\section{HASIL DAN PEMBAHASAN}

\section{Pengaruh Efikasi Diri Terhadap Komitmen Organisasi}

Hasil penelitan ini menunjukkan bahwa efikasi diri memberikan pengaruh positif secara langsung terhadap komitmen organisasi. Besarnya pengaruh tersebut ditunjukkan oleh $\mathbf{r}_{\text {hitung }} 0,630$ dan koefisien jalur 0,316 . Hasil penelitian ini senada dengan pendapat beberapa ahli di antaranya adalah menurut Schultz dan Schultz (2006:360) bahwa self-efficacy refers to the belief in one's ability to accomplish a task. Efikasi merujuk pada kepercayaan terhadap kemampuan seseorang untuk menyelesaikan suatu tugas. Sedangkan Robbbins dan Judge (2009:180) menyatakan self-efficacy is also an individual's belief that he is able to carry out a task. Pengertian ini dimaksudkan bahwa efikasi diri juga merupakan keyakinan individu bahwa dirinya mampu menjalankan suatu tugas.

Menurut Newstrom (2007:207), "organizational commitment is the degree to which an employee identifies with the organization and wants to continue actively participating in it." Komitmen organisasi merupakan derajat identifikasi diri pegawai dengan organisasi dan keinginan-keinginannya untuk meneruskan partisipasi aktifnya dalam organisasi. Sedangkan Mowdey, Porter dan Steers sebagaimana dikutip Slocum dan Hellriegel (2007:328) memberikan definisi komitmen organisasi sebagai berikut; "organizational commitment refers to the strength of an employee's involvement in the organizational and indentification with it, a support of and acceptance of the organization's goals and values, a willingness to exert considerable effort on behalf of the organization, and, a desire to remain with the organization." Komitmen organisasi merujuk pada kekuatan pegawai dalam mengidentifikasikan keterlibatan dirinya ke dalam bagian organisasi yang ditandai: penerimaan terhadap nilai-nilai dan tujuan organisasi, kesiapan dan kesediaan untuk berusaha dengan sungguh-sungguh atas nama organisasi, dan keinginan untuk mempertahankan keanggotaan di dalam organisasi.

Hasil penelitian terdahulu tentang pengaruh efikasi diri terhadap komitmen organisasi juga memperlihatkan hasil yang sesuai dengan hasil penelitian ini. Menurut Gillham, Reivich dan Shatté (2002:121) menyatakan bahwa "individuals with high selfefficacy is committed to solving the problem and will not give up when it finds that the strategies 
that are being used that did not work". Individu-individu dengan efikasi diri tinggi memiliki komitmen dalam memecahkan masalahnya dan tidak akan menyerah ketika menemukan bahwa strategi yang sedang digunakan itu tidak berhasil. Dalam konteks dinamika kehidupan organisasi, komitmen seperti itu sangat dibutuhkan terutama untuk memecahkan berbagai persoalan organisasi, termasuk pencapaian tujuan organisasi. Luthans (2008:346) juga mengatakan "In relation to achieve goal determination, there is difficulty to achieve a goal and commitment will be influenced by self-efficacy. With similar reason, advancement and achievement of a goal will influence self-efficacy." Berkaitan dengan penetapan tujuan, kesulitan mencapai tujuan dan komitmen akan dipengaruhi oleh efikasi diri. Dengan alasan yang sama kemajuan dan pencapaian tujuan akan mempengaruhi efikasi diri. Wright dan Noe (1996:353) menjelaskan, "self-efficacy is also an assessment of a person on himself or herself, whether he is successful to implement an activity. A person who has a high self-efficacy will more attempt to setttle-out impediment or obstacle". Efikasi diri juga merupakan penilaian seseorang atas dirinya, apakah ia dapat sukses melaksanakan suatu kegiatan. Seseorang yang memiliki efikasi diri tinggi akan lebih berupaya dalam mengatasi hambatan atau rintangan yang dihadapinya. Sedangkan Lussier (1996:81) berpendapat bahwa; "self-efficacy is capability owned to do something in special situation. Self-efficacy influences effort of a person, his or her persistence and interest in solvableness of difficulty from target that he or she selects." Efikasi diri merupakan kemampuan yang dimiliki untuk melakukan sesuatu dalam situasi yang khusus. Efikasi diri mempengaruhi upaya seseorang, kegigihannya dan minatnya dalam mengatasi kesulitan dari sasaran yang dipilihnya. Baron dan Greenberg (2003:205) menjelaskan, "self efficacy is a relatively new topic in the study of organizational behavior, but have been identified have important implications that could affect performance on many different tasks". Efikasi diri merupakan topik yang relatif baru dalam studi perilaku organisasi, tetapi telah diindentifikasi memiliki implikasi penting yang dapat mempengaruhi kinerja pada banyak tugas yang berbeda. Sedangkan Baron (1996:392) berpandangan bahwa, "selfefficacy is capability owned by a person in order to carry out action he wants. The higher the feeling of person about self-efficacy that he has, the better the tendency to do various duty. The success like that in the end has finnaly directed a person of positive feeling about himself or herself more comprehensively". Efikasi diri merupakan kemampuan yang dimiliki seseorang untuk dapat melaksanakan tindakan yang diinginkan. Semakin tinggi perasaan seseorang tentang efikasi diri yang dimilikinya maka semakin baik kecenderungannya untuk melakukan tugas yang lebih beragam. Keberhasilan seperti itu sudah tentu pada akhirnya dapat mengarahkan seseorang pada perasaan positif tentang dirinya secara lebih menyeluruh. Dengan demikian hasil penelitian ini semakin memperkuat teoriteori dan penelitian terdahulu tentang pengaruh efikasi diri terhadap komitmen organisasi. 


\section{Pengaruh Kepercayaan Terhadap Komitmen Organisasi}

Hasil penelitan ini menunjukkan bahwa motivasi kerja memberikan pengaruh positif secara langsung terhadap kreativitas. Besarnya pengaruh tersebut ditunjukkan oleh $r_{\text {hitung }} 0,771$ dan koefisien jalur 0,608. Hasil penelitian ini sejalan dengan pendapat Colquitt, LePine dan Wesson (2009:219), "trust is defined as thewillingnessto be vulnerable toa trustee based on positive expectations about the trustee's actionsand intentions." Kepercayaan merupakan suatu keinginan untuk menggantungkan diri pada suatu otoritas yang didasarkan pada pengharapan positif akan tindakan dan perhatian otoritas. Robbins dan Judge (2007:392-393) menyebutkan lima dimensi kunci dalam konsep kepercayaan, yaitu: integritas (integrity), kompetensi (competence), konsistensi (consistency), loyalitas (loyalty) dan keterbukaan (openness). Kelima dimensi ini merupakan modal penting bagi seseorang untuk dapat dipercaya. Ketika seorang pemimpin sebagai pemegang otoritas organisasi memiliki integritas, kompetensi, konsistensi, loyalitas, dan keterbukaan yang tinggi maka pemimpin tersebut layak untuk dipercaya. Manakala organisasi memiliki pemimpin-pemimpin seperti itu, maka organisasi tersebut layak untuk dipercaya pula. Apabila suatu organisasi dipenuhi orang-orang yang memiliki integritas, kompetensi, konsistensi, loyalitas, dan keterbukaan yang tinggi, maka dalam organisasi itu akan hidup subur rasa saling percaya. Ketika kondisi ini terbangun dengan baik dan solid, maka anggota organisasi tidak akan mengalami kesulitan dalam membangun komitmen organisasi, yang dimaknasi oleh Newstrom (2007:207) sebagai "the degree to which an employee identifies with the organization and wants to continue actively participating in it." Suatu tingkat atau derajat identifikasi diri pegawai dengan organisasi dan keinginan-keinginannya untuk meneruskan partisipasi aktifnya dalam organisasi, dan menurut Moore dalam Ivancevich, Konopaske, and Matteson (2008:198), “commitment to an organization involves three attitudes: (1) a sense of identification with the organization's goals, (2) a feeling of involvement in organizational duties, and (3) a feeling of loyalty for the organization." Komitmen organisasi ditandai oleh tiga aspek, yaitu: (a) suatu rasa identifikasi dengan tujuan-tujuan organisasi, (b) suatu perasaan keterlibatan dalam kewajiban-kewajiban organisasi, dan (c) suatu perasaan loyalitas terhadap organisasi. Para pegawai akan merasa ringan memperjuangkan tujuan organisasi dan secara suka rela melibatkan dirinya dalam berbagai aktivitas organisasi serta tetap bertahan dalam organisasi jika dalam organisasi hidup subur rasa saling percaya.

Hasil penelitian Kursad (2008:2293) juga menunjukkan bahwa "the trust had a positive effect on organizational commitment." Kepercayaan memiliki pengaruh positif terhadap komitmen organisasi. Demikian pula studi Nyhan (1999:58) membutikan bahwa kepercayaan memiliki pengaruh terhadap komitmen organisasional. McShane dan Von Glinow (2008:120), menjelaskan "trust refers to positive expectations one person has toward another person in situations involving risk. Trust means putting faith in the other person or group"." Kepercayaan merujuk pada suatu pengharapan positif seseorang terhadap orang lain pada suatu situasi yang melibatkan risiko. Kepercayaan juga berarti menyerahkan nasib pada seseorang atau kelompok lain. Sedangkan Robbins dan Judge (2007:392) berpandangan bahwa "trust is a positive expectation that another will not-through words, actions, or decisions-act opportunistically." Kepercayaan adalah suatu pengharapan positif bahwa pihak lain tidak akan - lewat perkataan, tindakan atau keputusan mengambil kesempatan melukai pihak lain. George dan Jones (2005:80) menyatakan bahwa, "trust is an expression of confidence in another person or group of people that you will not be put at risk, harmed, or injured by their actions". Kepercayaan adalah ungkapan keyakinan terhadap orang lain atau kelompok orang di mana Anda tidak akan berisiko, 
dihancurkan, atau dilukai oleh tindakan mereka. Sedangkan Rousseau et. al. sebagaimana dikutip Mollering (2006:7) memberikan definisi "trust as a psychological state that consists of a willingness to accept an unpleasant situation that is based on positive expectations of a desire or behavior of another party". Definisi tersebut menekankan makna bahwa kepercayaan merupakan suatu keadaan psikologis yang terdiri dari keinginan untuk menerima suatu keadaan yang tidak menyenangkan yang didasarkan pada pengharapan positif akan keinginan atau perilaku pihak lain. Hal ini mengisyaratkan bahwa hasil penelitian ini sesuai dan memperkokoh hasil penelitian sebelumnya mengenai pengaruh kepercayaan terhadap komitmen organisasi pegawai.

\section{Pengaruh Efikasi Diri Terhadap Kepercayaan}

Hasil penelitan ini menunjukkan bahwa supervisi memberikan pengaruh positif secara langsung terhadap motivasi kerja. Besarnya pengaruh tersebut ditunjukkan nilai koefisien korelasi sebesar 0,516 dan nilai koefisien jalur sebesar 0,516.

Hasil penelitian ini sejalan dengan pendapat Lussier (1996:81) yang menyatakan bahwa, "self-efficacy is capability owned to do something in special situation." Efikasi diri merupakan kemampuan yang dimiliki untuk melakukan sesuatu dalam situasi yang khusus". Efikasi diri mempengaruhi upaya seseorang, kegigihannya dan minatnya dalam mengatasi kesulitan dari sasaran yang dipilihnya. Menurut Looney, Valaich dan Akbulut (2004:3), efikasi diri memiliki tiga dimensi, yaitu: generalitas (generality), besaran (magnitude), dan kekuatan (strength). Efikasi diri yang tinggi, yang memungkinkan seseorang dapat menuntaskan pekerjaan dengan cepat dan berkualitas, merupakan good will penting bagi seseorang untuk membangun kepercayaannya.. Menurut Colquitt, LePine dan Wesson (2009:219), "trust is defined as thewillingnessto be vulnerable toa trustee based on positive expectations about the trustee's actionsand intentions. Kepercayaan merupakan suatu keinginan untuk menggantungkan diri pada suatu otoritas yang didasarkan pada pengharapan positif akan tindakan dan perhatian otoritas.

Hasil penelitian terdahulu yang dilakukan oleh Kim (2005:1), "self efficacy had a significant effect on trust". Efikasi diri berpengaruh signifikan terhadap kepercayaan. Demikian pula hasil penelitian $\mathrm{Wu}$, Wang dan Liu (2012:1) juga membuktikan bahwa efikasi diri sosial berpengaruh terhadap kepercayaan sosial. Dengan demikian hasiul penelitian ini sesuai dan memperkukuh hasil penelitian sebelumnya mengenai pengaruh efikasi diri terhadap kepercayaan pegawai..

\section{PENUTUP}

Kesimpulan: (1) Terdapat pengaruh positif efikasi diri terhadap komitmen organisasi pegawai Dinas Pendidikan Provinsi Papua Barat. Temuan ini bermakna bahwa efikasi diri yang tinggi dapat meningkatkan komitmen organisasi pegawai, (2) Terdapat pengaruh positif kepercayaan terhadap komitmen organisasi pegawai Dinas Pendidikan Provinsi Papua Barat. Ini berarti kepercayaan diri yang tinggi dapat meningkatkan komitmen organisasi pegawai, (3) Terdapat pengaruh positif efikasi diri terhadap kepercayaan pegawai Dinas Pendidikan Provinsi Papua Barat. Temuan ini bermakna bahwa efikasi diri yang tinggi dapat meningkatkan kepercayaan pegawai.

Saran: saran untuk Dinas Pendidikan Provinsi Papua Barat perlu menyosialisasikan tentang pentingnya peningkatan efikasi diri pegawai bagi peningkatakan kepercayaan dan komitmen organisasi pegawai yang diperlukan untuk membangan kinerja yang optimal dan mencapai tujuan organisasi. 
Kedua, perlu menekankan pentingnya kepercayaan pegawai bagi peningkatan komitmennya pada organisasi. Upaya yang dapat dilakukan sehubungan dengan hal itu adalah teladan dari unsur pimpinan mengenai integritas, kompetensi, konsistensi, loyalitas dan keterbukaan yang dibutuhkan dalam bekerja secara efektif.

\section{DAFTAR RUJUKAN}

Baron, Robbert A., dan Greenberg, Jerald, Behavior in Organizations. New Jersey: Pearson, 2003..

Baron, Robert A., Essentials of Psychology. Boston: Allyn and Bacon, 1996.

Carlson, Neil R., dan Buskist, William, Psychology: The Science of Behavior. Boston: Allyn and Bacon, 1999.

Colquitt, Jason A., Jeffery A. Lepine and Michael J. Wesson, Organizational Behavior: Improving Performance and Commitment in the Workplace. New York: McGraw-Hill Companies, Inc., 2009.

George, Jennifer M., dan Jones, Gareth R., Understanding and Managing Organizational Behavior. New Jersey: Pearson Education, Inc., 2005.

Gibson, James L., Ivancevich, Jahn M., dan Donnelly, James H., Organizations. New York: Richard Irwin, 2010.

Gillham, J.E., Reivich, K.J., dan Shatté, A.J. , "Positive youth development, prevention and positive psychology: Commentary on Positive youth development in the United States". Prevention and Treatment, 5, Article 18., 2002.

Kim, Y. H., dan Kim, D.J., "A Study of Online Transaction Self-Efficacy, Consumer Trust, and Uncertainty Reduction in Electronic Commerce Transaction," Proceedings of the 38th Annual Hawaii International Conference on System Sciences, 2005, 1.

Lussier, Robert N., Human Relations in Organizations: A Skill Building Approach. Chicago: lrwin,1996.

Luthans, Fred, Orgnazational Behavior, 11 th edition. Boston: McGraw-Hill, 2008.

McShane, Steven L., dan Glinow, Mary Ann Von, Organizational Behavior. New York: McGraw-Hill, 2008.

Mollering, Guido, Trust: Reason, Routine, Reflexivity. Oxford, Elsevier, 2006.

Newstrom, John W., Organization Behavior: Human Behavior at Work. Boston: McGraw Hill, 2007.

Nyhan, Ronald C, "Increasing Affective Organizational Commitment in Publlic Organizations", Review of Public Personnel Administration, Vol. 19 No. 3, 1999, 5870. 
Redman, Tom and Wilkinson, Adrian, Contemporary Human Resource Management. Great Britain, Prentice Hall, 1999.

Robbins, Stephen P., dan Judge, Timothy A, Organizational Behaviour. New Jersey: Pearson Education, Inc., Upper River, 2007.

Schultz, Duane dan Schultz, Sydney Ellen, Psychology $\mathcal{E}$ Work Today. New Jersey: Pearson Prentice Hall, 2006.

Slocum, John W., dan Hellriegel, Don, Fundamental of Organizational Behavior. Australia: Thomson-South Western, 2007.

Wright, Patrikc M., dan Noe, Raymond A., Management of Organizations. Chicago: Irwin, 1996.

Wu, Sheng-Yi, Wang, Shih-Ting, dan Liu, Eric Zhe-Feng, "The influences of social-self efficacy on social trust and social capital - A Case Study of Facebook," TOJET: Tuskish Journal of Educational Tecknology, April 2012, Volume 12 Issue 2, 1.

Yilmaz, Kursad, "The Relationship Between Organizational Trust and Organizational Commitment in Turkish Primary Schools." Journal of Applied Sciences, 8 (12), 2008, 2293-2299. 